\title{
〔54 56〕高分子異性体に関する研究
}

第 1 報 無秩序に置換されれ分子と選択的に置換されれ分子

(1953 年 4 月 23 日受理)

桜田一郎*・吉 崎修*

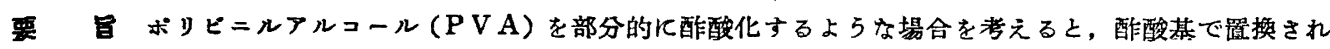
る水酸基の位置の租み合せによって，同一置換度の分子についても非常に多くの買性体の存在が考えられる。 てれらの異性体中極端に異る 2 種の型として, 置換が糸状分子に沿って算秩序に比較的平均して起っている型 そ，栄状分子の各部分に選抧的に集中的に起っている型の 2 種が考えられる。前者を無秩序置換分子，後者を 選択的置換分子に命名する。PVAの部分ホルマール化によっててれら 2 種の型の分子を合成した。前者はP VAの水溶液から出発して, 均一系でホルマール化を行らことにより, 後者は PVAのフィルムを不均一系で ホルマール化することによって得られて。これらの分子の固体の椿造を考えると，無秩序分子には問題はない

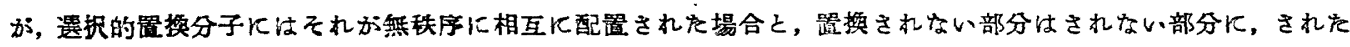
部分岋された部分に相接近，対応して配置された選択的配置の 2 種が考えられる。無秩序分子が無秩序に配圈

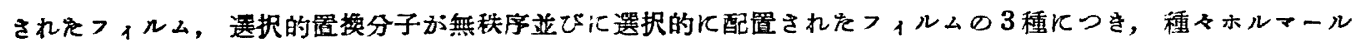
化度を異にする場合の比重を測定し，3種のフィルムは明瞭に買る比重を示すことを明らかにした。

\section{緒言}

高分子化合物において例えばポリビニルアルコール（PVA）のよらな禾状分子を酶酸化した場 合を考える。とのよらな部分酰酸化物は系状分子のどのような位置が酶酸化されているかてよって 多数の異性体を与える。いま重合度 $P$ すなわち $P$ 個の遊離の水酸基を有する P V A 分子において $\boldsymbol{R}$ 個え゙酶酸化されを場合の異性体の数を計算す る。それはちよらど個の異るすのから $\boldsymbol{R}$ 個をとり

a

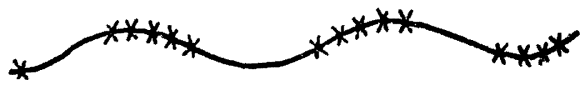
出す場合の組み合せの数に等しいから，その数は ${ }_{p} C_{r}=P ! / R !(P-R) !$ となる。とのような多数の 個々の異性体をとりあげて論議の対照とするとと は困難であるから，多数の異性体中極端沉異る2 種の型式を選んで炊のように命名する。

\section{無秩序置換分子}

選択的置换分子 randomly substituted molecule selectively substituted molecule

\footnotetext{
* 京都大学工学部維維化学教室（京都市左亲区吉田本町）
} 
以後簡単化して, 前者を無秩序分子, 後者を選択的分子と呼ぶならば, 無秩序分子においては酢 酸化等の置換反応が，糸状分子に沿って全く無秩序に第 1 図 b のでとく起っている場合であり，選 択的分子においては置換反応が禾状分子の各部分に括んて集中的かつ選択的に起っている第 1 図 $\mathrm{c}$ のよらな場合である。

PVAの反応を均一系で行らょうな場合, 特に置換反応が平衡関係によって規定されるような場 合には一応無秩序分子の生成が期待される。これに対して固体のP V A 第 2 図aに示されたよ 5に結晶部分と非結晶部分から成立しているが,とのような固態高分子に置換反応を行う場合には， セルロースの固態の化学反応てつんて多くの実験で知られ, またPVAの乾燥物のホルマール化に おいてわれわれの研究室で明らかてされたよらに適当条件では第 2 図 bのでとく非結旨部分にのみ

a

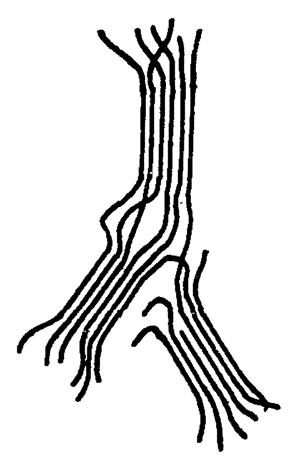

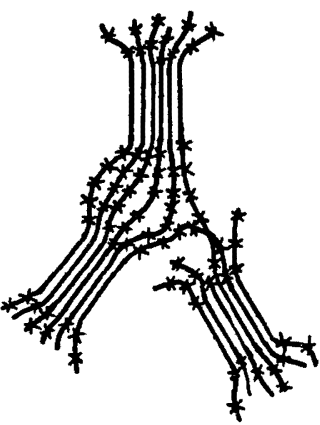

b
第 2 図 $a$ ：結晶部分と非結晶部分から成 立する高分子固体

b : a の非結晶部分のみが反応を 受けた状㿟

反応は起り，結晶部分は反応しなん。この場合個 ふの分子をとり出して眺めてみるとそれは第1図 cのような構造をるっている筈である。従って上 述の 2 種の型の分子は一応実験的に実現できる。

無秩序分子につんてはその固態の構造は，系状 分子の平行排列，さらに一定方向への瀻維状配列 等の可能性は考えられるが，それ以上の椱猚性は ない。しかし選択的分子につんてはその固態構造 を考える場合に上のような配列のほかてさらに複 雑性がある。それはこのような紎分子が相互に 無秩序行第 3 図のととく配置される場合と，反応 しない部分はしない部分に，反応した部分はした 部分に対応して第 2 図bのよ5な選択的配置をとる場合である。

高分子固体につレて，その物理化学的性躓例えば膨潤性を研 究するとすれば，その眾換度は同一であっても，次の 3 個の場 合を区別する必要がある。

1. 無秩序分子の無秩序配置

2. 選択的分子の無秩序配置

3. 選択的分子の選択的配置

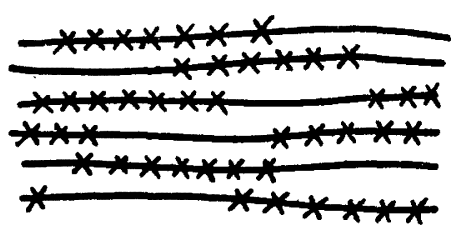

第 3 图選択的盖換分子の哭 秩序配是

本報告においては無秩序分子，選択的分子の生成法ならびに固体における上記の各種配置の実現 法をPVAの部分ホルマール化物につんて説明し，またてれらの固体のホルマール化度が同一であ っても，その比重を異てするととを述へ，次報以下におんて，水その他の溶都を用いる膨潤実騟に つレて報告する。 


\section{1. 無秩序置換分子の生成法}

さきて藤本”はPVAを水溶液で硫酸を触媒にしてホルムアルデヒドでホルマール化する場合に はホルマール化度 $40 \mathrm{~mol} \%$ 以下ておいては反応は殆んど均一系で進行し, 使用されたホルム厂 ルデヒドの殆んど全部はホルマール化反応により，またとの祭ホルマール化は可逆反応で平衡関係 が成立するととを明らかにした。 PVA の無秩序ホルマール化物はとの研究をもとにして合成さ れた。

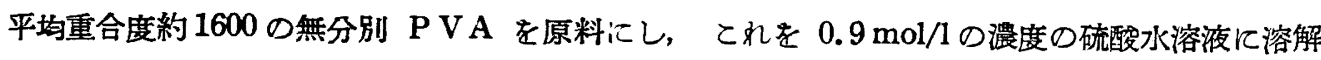
しおのおの所要量のホルムアルデドを加え, $40{ }^{\circ} \mathrm{C} て ゙ 20$ 時間反応を行った。高度のホルマール 化物は反応後沈祋するが, 低度のホルマール化物はアセトンで沈澱し，適宜メタノール，アセトン， 水等で洗潗, 精製, 乾燥した。このようにして無秩序てホルマール化されたP VAが得られたわけ である。

てれから無秩序配置フイルムを得るためには, 水溶性のものは水に溶解し, 水不溶のるのは水, ビリジンス溶解し, ガラス板上に流し常温附近でフィルムをつくり, 風乾後 $80{ }^{\circ} \mathrm{C}$ で減圧乾燥し た。フィルムの厚さは約 $0.15 \mathrm{~mm}$ である。

ホルマール化度 $60 \%$ 以上のものはてのような方法ではフィルムにできなかった。

このよライして得られた試料のホルマール化度並びに浮沈法で四塩化炭素一一石油エーテルの二 成分系で測定した比重を示すと第 1 表のととくである。

第1表無秩序にホルマール化された PVAのホルマール化度を，それょり得ら．

れた無秩原配置〉ィルムの比重

\begin{tabular}{lc|c|c|c|c|c|c|c|c|c}
\hline \hline ホルマール化度 モル\% & 0 & 6.4 & 12.2 & 18.2 & 28.9 & 34.6 & 39.6 & 43.7 & 53.4 \\
\hline 更 $D_{4}^{30}$ & 1.2940 & 1.2838 & 1.2697 & 1.2602 & 1.2572 & 1.2546 & 1.2536 & 1.2528 & 1.2507 \\
\hline
\end{tabular}

\section{2. 選択的置換分子の生成法}

PVAょりビニロンの製造工程に関する当研究室の研究によれば，熱処理した P V A 䋻維を普通 の条件下穴水溶液で硫酸を触媒としてホルマール化す礼ば，PVA瀻維は反応前後を通じて僅江膨 潤するのみであり，ホルマール化反応は 30〜40 モル\%程度迄は容易に進行し，そのX線図は原料

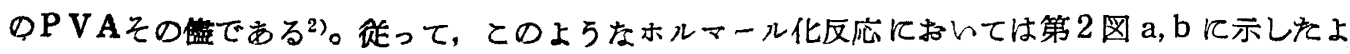

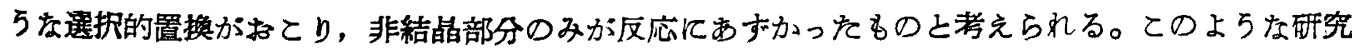
を基礎に，下のよらな条件で反応を行った。 
前項之同一のPVAの $10 \%$ 水溶液を, 水銀上て浮べだラス板上て流し, 減圧乾燥して純 P V

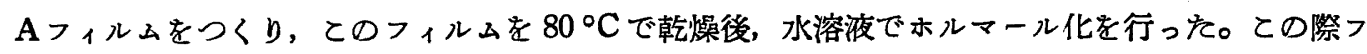
ィルム葆かに膨潤するだけで反応は終始異相系で起る。ホルマール化の条件は下のごとくです る。 $\mathrm{H}_{2} \mathrm{SO}_{4} 200 \mathrm{~g} / 1, \mathrm{Na}_{2} \mathrm{SO}_{4} 200 \mathrm{~g} / 1$ の水溶液に種々の量のホルムアルデヒドを加え, 浴比 40 倍, 浴温 $60^{\circ} \mathrm{C}$ で 10 時間ホルマール化反応を行ん, 種ふホルマール化度を異にする選択的置換物を得 な。とのよらなフィルムそのままでは分子は選択的配置をとっている。フィルムの厚さは $0.10 \pm$ $0.01 \mathrm{~mm}$ である。

次に無秩序配置フィルムを得るためには上の試料を水一ピリジンの二成分系に溶解し,ガラス板上

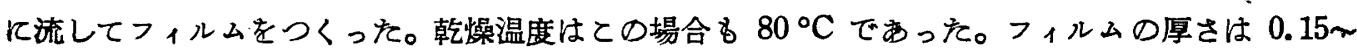
$0.08 \mathrm{~mm}$ である。との方法ではホルマール化度 $60 \%$ 以上のるのは溶解せす無秩序フィルムを得 ることは困難であった。

第 2 表はホルマール化度を異てする種々の無秩序並びて選択的配置フィルムてついて上と同棣の 浮沈法で比重を測定した結果を示したものである。

第 2 表 選択的にホルマール化されたPVAから得られを無秩序並びに選択 的配置フィルムの比重

\begin{tabular}{|c|c|c|c|c|c|c|c|c|c|c|c|c|}
\hline \multicolumn{2}{|c|}{ ホルマール化度 } & 0 & 5.2 & 12.3 & 22.1 & 25.6 & 32.2 & 40.9 & 50.3 & 55.0 & 64.7 & 70.5 \\
\hline 比南 & 無秩序フィルム & 1.2940 & 1.2842 & 1.2792 & 1.2731 & 1.2718 & 1.2344 & 1.2313 & 1.2305 & 1.2271 & - & - \\
\hline$D_{4}^{30}$ & 選択的配置フィルム & 1.2940 & 1.2934 & 1.2909 & 1.2785 & 1.2810 & 1.2731 & 1. 2665 & 1.2615 & 1.2568 & 1.2516 & 1.2474 \\
\hline
\end{tabular}

\section{3. 各種フィルムの比亚につレて}

第 1 表及び第 2 表に，無秩序置換分子から得られた無秩序配置フィルム，選択的置換分子から得 られを無秩序並びて選択的配置フィルムの比重の測定值を示したが，これらの関係を横軸てホルマ 一ル化度，縦軸て比重をとって図示すると第 4 図のでとくになる。第 4 図を見て第 1 亿注意すべ ことはこれら 3 種のフィルムが同一ホルマール化度の下に明らかて異る比重を示すといらととであ る。との事実から，上て説明した 3 種のフィルムの分子的な構造の差異は単て推定でなく，現実の ものであるととがわかる。

選択的置換分子の選択的配置フィルムの比重が全体として最も高いが，てれは選択的配置により， 分子の純P VAの部分が結晶を形づくっているのであるから当然であろう。ホルマール化度が高く なるにつれて比重は減少するが，ホルマール化度 $10 \%$ 附近にクニックがあり, それ以後再線的に 減少する。この選択的置換分子が，無秩序の配置をとる場合にはホルマール化度 $30 \%$ 附近で比重 
は極めて急激て減少し，ての点におんて 固体の構造上何等かの急激な葆化のあ。 をととを思わせる。とれは $30 \%$ 程度の ホルマール化度迄は分子中に存在する集 団的な $\mathrm{OH}$ 基の影繁で，固体の構造が幾 分選択的配置に近いととによるるのでは あるまいかと考えられるが確実なとこは 現在不明である。無秩序分子の無秩序に 配置されたフィルムでは比重は20モル％ のホルマール化度迄急激に減少し, それ 以後の減少は緩で西る。てのクニックが 何飞原因するかはいまのとてろ明らかで ないがややはり多数に存在する $\mathrm{OH}$ 基の 水素結合による旁引力のあらわれではな レかと思加る。

\section{交献}

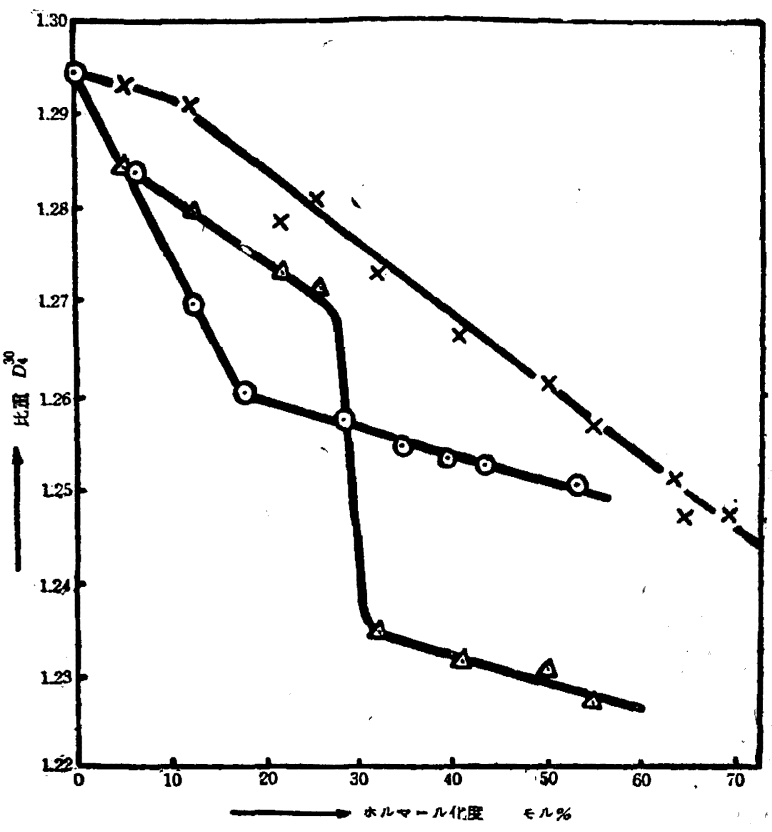

○與秩序小ルマール化分子の無秩序配置フィルム

$\Delta$ 選択的ホルマール化分子の無秩序配置フィルム

×選択的水ルマール化分子の選択的配置フィルム

第4図各種フィルムのホルマール化度と比重の関保

1) 藤本, 大杉, 桜田: 高化 714 (1950)

2）桜田, 渐野：理研報 20898 (1941)

第 2 報無秩序並びに選択的にホルマール化されれ

ポりビニルアルコール皮膜の水による膨潤性

(1953 年 4 月 23 日受理)

桜田一郎・吉 崎修

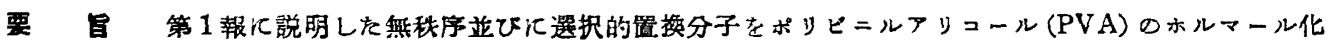
反広に上りつくり，無秩序ホルマール化PVAの無秩序配置〉ィルム，選択的ホルマール化 PVAの無秩序並び

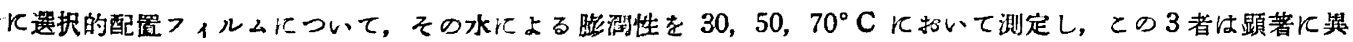
る挙動を示すととを確めた。 